\title{
Planned Relocations in the Context of Climate Change: Unpacking the Legal and Conceptual Issues
}

\author{
Jane McAdam* and Elizabeth Ferris**
}

\begin{abstract}
Over the past six or so years, a wealth of research has sought to analyse conceptually, and document empirically, the links between climate change and human migration and displacement. However, considerably less attention has been given to planned relocations made necessary by the effects of climate change. This article seeks to contribute to the emerging policy debates over relocation as a form of adaptation to climate change. It begins by examining conceptual issues related to 'relocation' in light of existing normative frameworks, before turning to policy challenges about how relocations are-or could be-used in practice. Indeed, the challenges raised by relocation are closely linked to how it is conceptualised, since this impacts on how particular movements are understood, who takes responsibility for them, over what timeframe, and in what manner. Many of the examples are drawn from the Pacific, a region where the impacts of climate change are already being felt and movements are already occurring. In particular, historical cases of relocation in the Pacific, whether for environmental or other reasons, provide insights and analogies that may be useful for contemporary policy deliberations.
\end{abstract}

\section{Keywords}

Relocation, Resettlement, Climate Change, Disasters, Law, Conceptualisation, Displacement, Migration

\section{Introduction}

Climate change is expected to make certain areas of the earth uninhabitable, which in turn will lead to new patterns of population movements. As conditions deteriorate, some people will leave before they are forced to do so. Some will move in anticipation

* Scientia Professor of Law and Director of the Andrew \& Renata Kaldor Centre for International Refugee Law, Faculty of Law, University of New South Wales (Australia). This research was funded by an Australian Research Council Future Fellowship.

** Director of the Brookings-LSE Project on Internal Displacement and Senior Fellow in Foreign Policy, Brookings Institution (US). This research was funded by the John D and Catherine $\mathrm{T}$ MacArthur Foundation.

The authors would like to thank Sanjula Weerasinghe for her helpful comments, and Kunal Sharma for research assistance. Any errors or omissions remain, of course, with the authors. 
or in response to a sudden-onset disaster. Those without the means to migrate will likely experience worsening conditions until at some point they have no other option but to leave their communities. In yet other cases, governments will decide that certain communities must be relocated for their own safety, or some communities will decide to move on their own.

While the relationship between climate change and mobility has been a growing concern among humanitarian, development, and human rights groups for some time, governments have been slow to consider mobility as a strategy to adapt to climate change. Instead, they have tended to focus on the importance of mitigation measures which (if successful) would make such movements unnecessary.

There were indications that this might be beginning to change at the international climate change negotiations in Cancún in December 2010 (COP 16), when states adopted the Cancún Adaptation Framework. Paragraph 14(f) invited states to 'enhance action on adaptation' by undertaking ' $[\mathrm{m}]$ easures to enhance understanding, coordination and cooperation with regard to climate change induced displacement, migration and planned relocation, where appropriate, at national, regional and international levels. ${ }^{1}$

Although the provision is not legally binding, it has already had some operational significance. Indeed, the intergovernmental Nansen Initiative on Disaster-Induced CrossBorder Displacement was launched in 2012 as a direct response, with the aim of gathering and collating data from five regions especially affected by disasters and climate change, to guide the development of legal and policy responses at the national, regional and international levels. Its methodological approach to information-gathering follows the three modes of mobility identified in the Framework (displacement, migration, planned relocation) and the levels for action (national, regional and international, although local is added as well). ${ }^{2}$ In this sense, the Cancún resolution has already had a 'catalytic role. ${ }^{3}$

Over the past six or so years, a wealth of research has sought to analyse conceptually, and document empirically, the links between climate change and human migration and displacement. However, considerably less attention has been given to planned relocation made necessary by the effects of climate change. For example, a review of governments' National Programmes of Action (NAPAs) reveals only a smattering of references to planned relocation as an adaptation strategy. Even in cases where relocation is mentioned, it is usually only in passing with no indication of the scale, timing, or areas

1 UNFCCC (9th Plenary Meeting), 'The Cancún Agreements: Outcome of the Work of the Ad Hoc Working Group on Long-Term Cooperative Action under the Convention' (10-11 December 2010) UN Doc FCCC/ CP/2010/7/Add.1.

2 Nansen Initiative on Disaster-Induced Cross-Border Displacement, 'Human Mobility, Natural Disasters and Climate Change in the Pacific' (Report from the Nansen Initiative Regional Consultation, Rarotonga, 2124 May 2013) (Nansen Initiative Pacific Report) <http://www.nanseninitiative.org/pacific-consultationsintergovernmental/> accessed 3 June 2015.

3 Koko Warner, 'Climate Change Induced Displacement: Adaptation Policy in the Context of the UNFCCC Climate Negotiations' (2011) UNHCR Protection Policy Research Series, PPLA 2011/02, 17 <http://www. unhcr.org/4df9cc309.html> accessed 4 August 2015. 
where it may be needed. ${ }^{4}$ Fiji is a rare example of a country that has created national guidelines on planned relocations made necessary by the effects of climate change. ${ }^{5}$ At the international level, policymakers are only just beginning to consider the issue, as evidenced by meetings held in Sanremo in March 2014 and Bellagio in May $2015 .{ }^{6}$

This article seeks to contribute to the emerging policy debates about relocation as a form of adaptation to climate change. As the Nansen Initiative explains, planned relocation may be an adaptive strategy in three contexts. First, it may be used as a preventative measure within a country to move people out of particularly hazardous areas, and thereby reduce the risk of future displacement. Secondly, it may be used as a durable solution within a country to enable people who have already been displaced to rebuild their lives elsewhere if it is not safe for them to return home. Thirdly, and exceptionally, relocation in another country may be a durable solution if large parts (or the whole) of the country of origin are rendered unfit for habitation. ${ }^{7}$

The article begins by examining conceptual issues related to 'relocation' in light of existing normative frameworks, before turning to policy challenges about how relocations are-or could be-used in practice. Indeed, the challenges thrown up by relocation are closely linked to how it is conceptualised, since this impacts on how particular movements are understood, who takes responsibility for them, over what timeframe, and in what manner. Many of the examples are drawn from the Pacific, a region where the impacts of climate change are already being felt and movements are already occurring. Further, historical cases of relocation in the Pacific, whether for environmental or other reasons, provide insights and analogies that may be useful for contemporary policy deliberations. Finally, it should be noted that most of the discussions about relocation

4 See Jane McAdam, Climate Change, Forced Migration, and International Law (OUP 2012) app. The following countries mention that relocations may be necessary as part of their country's adaptation strategies: Bhutan, Eritrea, Gambia, Kiribati, Malawi, Maldives, Mauritania, Mozambique, Samoa, São Tome and Príncipe, Senegal, Solomon Islands, Tanzania, Tuvalu, Uganda and Vanuatu.

5 Catherine Wilson, 'Fiji Leads Pacific Region on Climate Adaption Efforts' (Inter Press Service, 25 May 2014) <http://www.ipsnews.net/2014/05/fiji-leads-pacific-region-climate-adaptation-efforts/> accessed 3 June 2015.

6 Sanjula Weerasinghe and others, 'Planned Relocations, Disasters and Climate Change: Consolidating Good Practices and Preparing for the Future' (UNHCR, Brookings and Georgetown University, Sanremo Report, 12-14 March 2014) (Sanremo Report) <http://reliefweb.int/sites/reliefweb.int/files/resources/54082cc69. pdf $>$ accessed 3 June 2015; Sanjula Weerasinghe and others, 'Planned Relocations in the Context of Climate Change' (UNHCR, Brookings and Georgetown University, Bellagio Consultation, 18-22 May 2015) (Bellagio Consultation) <http://www.brookings.edu/about/projects/idp/planned-relocations> accessed 3 June 2015. See also the background report prepared for the Sanremo meeting: Elizabeth Ferris, 'Planned Relocations, Disasters and Climate Change: Consolidating Good Practices, Preparing for the Future: Background Document: Sanremo Consultation' (UNHCR Brookings and Georgetown University, Sanremo Consultation, 12-14 March 2014) <http://www.unhcr.org/53c4d6f99.pdf> accessed 3 June 2015.

7 Nansen Initiative on Disaster-Induced Cross-Border Displacement, 'Cross-Border Displacement in the Context of Disasters and Climate Change: A Protection Agenda’ (8 April 2015) para 62 (Nansen Initiative Draft Protection Agenda) <http://www.nanseninitiative.org/global-consultations/> accessed 3 June 2015. 
as an adaptation strategy relate to internal, rather than cross-border, movement. ${ }^{8}$ This is mainly because it is incumbent on national governments to ensure that people are not living in precarious environments, but also because there is currently no political appetite to formulate policies on the relocation of communities across international borders. Additionally, cross-border relocation is unlikely to be required except in very limited and extreme cases, such as small island states whose long-term habitability is uncertain. Even then, migration (by individuals and households) rather than relocation (by communities) is likely to be a more common strategy.

\section{The irksome issue of definitions}

'Relocation' and 'resettlement' are terms frequently used in the literature, but there is a striking lack of clarity about their meaning. ${ }^{9}$ Slippages between terms such as 'relocation', 'planned relocation', 'resettlement', 'evacuations' and 'displacement' are common, even though the contexts in which they are discussed reveal that they are not necessarily synonymous. While the distinctions may seem purely semantic, they matter when terms are used by policymakers and advocates to make decisions about where people will live or what legal status they will have. It is also important to be clear about how these terms relate to one another. As the report of an expert meeting held in Sanremo in March 2014 makes clear, even those who have worked in related fields for decades do not agree on the usage of the terms 'relocation' and 'resettlement.'

We suggest here that the term 'relocation' generally refers to the physical process of moving people and can be voluntary or forced, large-scale or small-scale. ${ }^{11}$ Unlike 'evacuations', relocations are intended to be permanent. For the past 50 years or so, most planned relocations have occurred in the context of development projects and, largely at the initiative of the multilateral development banks, have included a process of resettlement, discussed below. There are also cases where communities have taken the initiative to relocate, petitioning their government or local authorities for support.

8 As McAdam has noted, historical examples of cross-border relocation amplify its challenges: Jane McAdam, 'Historical Cross-Border Relocations in the Pacific: Lessons for Planned Relocations in the Context of Climate Change' (2014) 49 J Pac Hist 301.

9 Thus, for example, the World Bank's Global Facility for Disaster Reduction and Recovery defines relocation as 'a process whereby a community's housing, assets, and public infrastructure are rebuilt in another location': Abhas K Jha and others, 'Safer Homes, Stronger Communities: A Handbook for Reconstructing after Natural Disasters' (World Bank Global Facility for Disaster Reduction and Recovery 2010) 77, 365 <http://www.gfdrr.org/sites/gfdrr/files/publication/SaferHomesStrongerCommunitites.pdf> accessed 4 June 2015.

10 Sanremo Report (n 6).

11 Elizabeth Ferris, 'Protection and Planned Relocations in the Context of Climate Change' (2012) UNHCR Legal and Protection Policy Research Series, PPLA/2012/04, $11<$ http://www.brookings.edu/ /media/ Research/Files/Papers/2012/8/protection\%20climate\%20change\%20ferris/protection\%20climate\%20 change\%20ferris.pdf> accessed 3 June 2015. 
The concept of 'resettlement', as used by those working with communities relocated as part of a development project, refers to a process to assist relocated persons to replace their housing, assets, livelihoods, land, access to resources and services; to maintain their communities; and to enhance, or at least restore, their living standards. ${ }^{12}$ In other words, the term 'resettlement' connotes not just the physical transfer of people, but also the process of restoring (and, where possible, improving) socio-economic conditions. ${ }^{13}$

Thus, this article distinguishes between 'relocation' as the physical movement of people and 'resettlement' as the process of restoring communities and socio-economic conditions. Relocations can be carried out without resettlement (for example, when a government transports urban squatters to the outskirts of a city and leaves them there without providing housing or ensuring access to public services), ${ }^{14}$ but resettlement (in our context) is only carried out when people are relocated.

We note that this conceptualisation differs from that used in both the report of the 2014 Sanremo consultation and the May 2015 Bellagio consultation. The latter defined 'planned relocation' as:

a planned process in which persons or groups of persons move or are moved away from their homes, settled in a new location, and provided with the conditions for rebuilding their lives. Planned Relocation is carried out under the authority of the state, takes place within national borders, and is undertaken to protect people from risks related to disasters and environmental change, including the effects of climate change. ${ }^{15}$

Planned relocations differ from 'evacuations', which were described by the Sanremo meeting as follows:

in situations of urgency where risk is imminent, [an evacuation describes] the rapid physical movement of people away from the immediate threat or impact of a hazard to a safer place. The purpose is to move people as quickly as possible to a place of safety and shelter. It is commonly characterized by a short timeframe (from hours to weeks) within which

12 World Bank, 'World Bank Operations Manual' (December 2001, revised April 2013) OP 4.12-Involuntary Resettlement (World Bank Operations Manual) <http://web.worldbank.org/WBSITE/EXTERNAL/ PROJECTS/EXTPOLICIES/EXTOPMANUAL/0,,contentMDK:20064610 menuPK:64701637 pageP K:64709096 piPK:64709108 theSitePK:502184,00.html> accessed 23 July 2015; Asian Development Bank, 'Safeguard Policy Statement' (2009) ADB Policy Paper <http://www.adb.org/sites/default/files/ institutional-document/32056/safeguard-policy-statement-june2009.pdf $>$ accessed 3 June 2015. Note that the Asian Development Bank stipulates that the poor and vulnerable should be able to improve their living standards, not just restore them to pre-project vulnerability.

13 Note that this is distinct from the concept of refugee resettlement, which refers to refugees who are transferred from first countries of asylum to settle permanently in a third country (such as the United States, Canada or Australia).

14 Anna Kajumulo Tibaijuka, 'Report of the Fact-Finding Mission to Zimbabwe to Assess the Scope and Impact of Operation Murambatsvina by the UN Special Envoy on Human Settlements Issue in Zimbabwe' (United Nations, 18 July 2005) <http://ww2.unhabitat.org/documents/ZimbabweReport.pdf> accessed 3 June 2015; International Organization for Migration, 'Dimensions of Crisis on Migration in Somalia' (2014) Working Paper, Department of Operations and Emergencies Report <http://www.iom.int/files/live/ sites/iom/files/Country/docs/Dimensions-of-Crisis-on-Migration-in-Somalia.pdf > accessed 3 June 2015.

15 Bellagio Consultation (n 6). 
emergency procedures need to be enacted in order to save lives and minimize exposure to harm. Evacuations may be mandatory, advised, or spontaneous. ${ }^{16}$

Planned relocations are presently used in both developed and developing countries and in a variety of situations, ranging from the permanent resettlement of tens of thousands of people following the Japanese earthquake/tsunami/Fukushima disaster, to smallerscale efforts to move several hundred people from areas at risk of landslides in Uganda, and the resettlement of communities from the slopes of Mount Merapi in Indonesia.

This article focuses on government-led planned relocations in the context of climate change. Many scientific studies have documented the effects of climate change, including an expected increase in the frequency, intensity and unpredictability of natural hazards; acidification of oceans; desertification; coastal erosion; sea-level rise; and so on. ${ }^{17}$ As migration scholars have emphasised, it is the interaction between the effects of 'natural' phenomena-such as floods-and socio-economic factors-such as impoverishmentthat will make relocation necessary. ${ }^{18}$ For example, landslides may be due to both heavy rainfall and deforestation. It is impossible to attribute movement to climate change or disasters alone. Rather, it is a multi-causal phenomenon.

Ironically, the implementation of measures to mitigate the impacts of climate change may also increase the need for planned relocation. Most obviously, the construction of a hydroelectric plant intended to reduce reliance on fossil fuels may mean that communities need to be moved. In some countries, such as Colombia and Indonesia, a major cause of displacement has been palm oil cultivation, which is heralded as a way of decreasing carbon emissions through biofuels. ${ }^{19}$

Finally, as noted above, most planned relocations made necessary by the effects of climate change are expected to occur within an affected country's own borders. While international relocations may be necessary in some regions, such as the Pacific, these

16 Sanremo Report (n 6) 10, drawing on Global Camp Coordination and Camp Management Cluster, 'The MEND Guide: Comprehensive Planning Guide for Mass Evacuations in Natural Disasters' (2014) (MEND Guide) <http://www.globalcccmcluster.org/tools-and-guidance/publications/mend-guide> accessed 3 June 2015.

17 Leonard A Nurse and others, 'Small Islands' in Intergovernmental Panel on Climate Change, Climate Change 2014: Impacts, Adaptation, and Vulnerability (CUP 2014) ch $29<$ https://ipcc-wg2.gov/AR5/ images/uploads/WGIIAR5-Chap29_FINAL.pdf> accessed 3 August 2015.

18 See eg Government Office for Science (UK), 'Foresight: Migration and Global Environmental Change: Future Challenges and Opportunities: Final Project Report' (London 2011) <https://www.gov.uk/ government/uploads/system/uploads/attachment_data/file/287717/11-1116-migration-and-globalenvironmental-change.pdf $>$ accessed 3 June 2015.

19 Internal Displacement Monitoring Centre, 'Resisting Displacement by Combatants and Developers: Humanitarian Zones in North-West Colombia' (November 2007) <http://www.abcolombia.org.uk/ downloads/Resisting_Displacement_-_Humanitarian_zones_in_NW_Colombia.Nov07.pdf> accessed 3 June 2015; Kimberly M Carlson and others, 'Committed Carbon Emissions, Deforestation, and Community Land Conversion from Oil Palm Plantation Expansion in West Kalimantan, Indonesia' (2012) 109 Proc National Academy of Sciences 7559. 
will be on a relatively small scale. ${ }^{20}$ Nevertheless, they raise particular legal issues that are addressed briefly below.

\section{Conceptual issues}

\subsection{The nature of relocation: forced or voluntary movement?}

Relocations can be forced or voluntary, although the distinction is not a true dichotomy. Movement occurs somewhere along a spectrum, with forced movement at one extreme and voluntary movement at the other. Walter Kälin notes:

'Voluntary'-contrary to what the term suggests-does not mean to be able to decide in complete freedom. Rather, voluntariness exists where space to choose between realistic options still exists. 'Forced' on the other hand characterizes situations where realistic options to choose from are no longer available. Thus, we can speak of voluntary movements where the element of choice is preponderant, whereas displacement or forced relocation takes place where the space for choice is [more limited]. ${ }^{21}$

Paragraph 14(f) of the Cancún Adaptation Framework uses the term 'planned relocation' to emphasise the importance of preparation, with the objective that those who move will be resettled and have their livelihoods and incomes restored. ${ }^{22}$

Even if relocation is planned, people may not move 'voluntarily' but may be required to do so by government authorities.

In other cases, communities themselves may petition their governments or local authorities for support with relocation, such as in the Carteret Islands in Papua New Guinea and Newtok in Alaska. ${ }^{23}$ In these cases, although relocation is not imposed by an external authority, a coercive element is nonetheless present: deteriorating environmental conditions make moving away more viable than staying put.

20 No state is presently advocating relocations across national borders. Even states that recognise that international movement may at some point be necessary tend to emphasise voluntary migration, as in Kiribati's 'migration with dignity' initiative: see McAdam, Climate Change, Forced Migration, and International Law (n 4) 40-44.

21 Walter Kälin, 'Changing Climates, Moving People: Distinguishing Voluntary and Forced Movements of People' in Koko Warner and others (eds), Changing Climates, Moving People: Framing Migration, Displacement and Planned Relocation (2013) UN University Policy Brief No 8, 38, 40 <http://collections. unu.edu/eserv/UNU:1837/pdf11213.pdf> accessed 24 July 2015.

22 Elizabeth Ferris, 'Planned Relocation and Climate Change' in Koko Warner and others (eds), Changing Climates, Moving People: Framing Migration, Displacement and Planned Relocation (2013) UN University Policy Brief No 8, 31-32 <http://collections.unu.edu/eserv/UNU:1837/pdf11213.pdf> accessed 24 July 2015. Potentially, it could also be used to differentiate between planned and spontaneous movement (which might otherwise be described simply as 'displacement'), or between longer-term, organised movement and temporary, organised movement (ie 'evacuation').

23 Robin Bronen, 'Community Relocations: The Arctic and South Pacific' in Susan F Martin, Sanjula Weerasinghe and Abbie Taylor (eds), Humanitarian Crises and Migration: Causes, Consequences and Responses (Routledge 2014) 221. 
It is perhaps unsurprising that relocated communities are more likely to regard their move as 'successful' when they are well-informed, able to participate in all stages of the decision-making process, given adequate compensation (in the form of assets, incomes and economic opportunities), ${ }^{24}$ and have a sense of control over the choice of destination and the process of movement. ${ }^{25}$

An interesting illustration is provided by two cross-border relocations to Fiji in the mid-1940s: the relocation of the Banabans from Ocean Island in present-day Kiribati to Fiji in 1945, and the partial relocation of the Vaitupuans from present-day Tuvalu to Fiji from 1947. Ever since the early 1900s, when phosphate deposits were discovered on Ocean Island, the Banabans had been regarded as an 'awkward obstacle' to phosphate mining operations (jointly carried out by the UK, Australia and New Zealand). ${ }^{26}$ In 1942, Rabi Island in Fiji was purchased on the Banabans' behalf as a 'second home'essentially as an insurance policy against the time when Ocean Island might be rendered uninhabitable on account of the mining. Later that year, Ocean Island was occupied by Japan, who dispersed most of the Banabans across the colony. At the end of the Second World War, the British colonial authorities considered it expedient to move the Banabans straight to Rabi rather than back to Ocean Island. To this day, the Banabans claim that they were misled about the conditions in Rabi and the nature of the move, and that this was an unjust, forced relocation. ${ }^{27}$

By contrast, the Vaitupuans voluntarily purchased the island of Kioa in Fiji as a safeguard against future overpopulation. They were not motivated by imminent land scarcity or extreme environmental conditions, nor coerced by the authorities. Their choice to relocate has led to a very different, and much more positive, self-story, in which

24 Craig A Johnson, 'Governing Climate Displacement: The Ethics and Politics of Human Resettlement' (2012) 21 Environmental Politics 308, 313, referring to Clionadh Raleigh, Lisa Jordan and Idean Salehyan, 'Assessing the Impact of Climate Change on Migration and Conflict' (2008) World Bank Working Paper, 2627 <http://siteresources.worldbank.org/EXTSOCIALDEVELOPMENT/Resources/SDCCWorkingPaper_ MigrationandConflict.pdf> accessed 3 June 2015; Michelle Mitchell, 'Relocation after Disaster: Engaging with Insured Residential Property Owners in Greater Christchurch's Land-Damaged "Residential Red Zone”" (Brookings Institution 2015) <http://www.brookings.edu/research/papers/2015/06/planned-relocationsclimate-change-new-zealand-mitchell> accessed 3 June 2015; Elizabeth Ferris, 'Planned Relocations, Disasters and Climate Change' (Paper prepared for the Conference on Climate Change and Migration in the Asia-Pacific: Legal and Policy Responses, Sydney, 10-11 November 2011) <http://www.gtcentre.unsw. edu.au/sites/gtcentre.unsw.edu.au/files/Elizabeth\%20Ferris\%20paper.pdf > accessed 3 June 2015; Michael M Cernea and Kai Schmidt-Soltau, 'Poverty Risks and National Parks: Policy Issues in Conservation and Resettlement' (2006) 34 World Dev 1808; Michael Cernea, 'The Risks and Reconstruction Model for Resettling Displaced Populations' (1997) 25 World Dev 1569; Peter Penz, Jay Drydyk, and Pablo S Bose, Displacement by Development: Ethics, Rights and Responsibilities (CUP 2011).

25 Jon Barnett and Saffron J O’Neill, 'Islands, Resettlement and Adaptation' (2012) 2 Nature Climate Change 8, 10, referring to Roli Asthana, 'Involuntary Resettlement: Survey of Voluntary Experience' (1996) 31 Eco \& Pol Wkly 1468.

26 HC Deb 18 December 1975, vol 902, col 1857 (Sir Bernard Braine), referring (at col 1856) to notes of a meeting held in October 1945 between the British colonial authority and representatives of the British Phosphate Commission.

27 For a detailed analysis of the Banaba and Vaitupu cases, see McAdam, 'Historical Cross-Border Relocations in the Pacific' (n 8). 
they cast themselves as pioneering 'settlers' rather than forced migrants. ${ }^{28}$ As Teresia Teaiwa has observed that 'while Rabi Island's settlement (...) has become something of a historical controversy, Kioa was clearly settled by the choice of islanders by Vaitupu, and without as much drama. ${ }^{29}$

Today, both communities have very similar living conditions and both groups acknowledge that they are better off in material terms than if they had remained at home. ${ }^{30}$ However, for the Banabans, socio-economic gains are overshadowed by a sense of injustice and disempowerment about the initial move. ${ }^{31}$ This element of coercion is key to their ongoing perceptions about the success or otherwise of relocation.

More generally, the availability of livelihoods in the destination, the degree to which vulnerabilities are mitigated, and the wellbeing of the community after relocation may all impact on the community's own perception of whether or not their movement was voluntary or forced-and this may shift over time. For instance, if promised benefits are not forthcoming, or people feel that an injustice has been done to them, then these conditions may start to vitiate the consent given (at least psychologically). Connell argues that resettlement can create a particular kind of poverty if land, services and infrastructure are inadequate, factors which are likely to be exacerbated if communities move to unfamiliar environments with different kinds of livelihoods (such as from an atoll to a high island). Indeed, relocation may spur further displacement if resources for resettlement services are insufficient. ${ }^{32}$ The 'success' of a relocation also seems tacitly to shape the language that scholars use to describe it. It seems that when long-term needs have not been factored into the move, or have failed, people are more likely to be described (and describe themselves) as 'displaced', rather than resettled. ${ }^{33}$

\subsection{Consent}

Who decides when relocation is needed and how it should occur? Sometimes affected communities will suggest the relocation themselves (as did the Newtok in Alaska and the Carteret Islanders in Papua New Guinea), while at other times decisions will be made by external actors, such as state authorities or developers.

28 ibid.

29 Teresia K Teaiwa, 'Rabi and Kioa: Peripheral Minority Communities in Fiji' in Brij V Lal and Tomasi R Vakatora (eds), Fiji in Transition: Research Papers of the Fiji Constitution Review Commission (University of the South Pacific 1997) 132.

30 This was reinforced during the Pacific consultations held by the Nansen Initiative. Comparisons between different relocation experiences in the Pacific showed that the ability of affected communities to choose to relocate greatly impacted the success of the relocation effort: see Nansen Initiative Pacific Report (n 2) 21.

31 McAdam, 'Historical Cross-Border Relocations in the Pacific' (n 8) 325. See also John Connell, 'Population Resettlement in the Pacific: Lessons from a Hazardous History?’ (2012) 43 Aust Geographer 127, 139.

32 Connell (n 31) 138-39.

33 Ferris (n 22) 32. See also Michael M Cernea and Christopher McDowell, 'Introduction: Reconstructing Resettlers' and Refugees' Livelihoods' in Michael M Cernea and Christopher McDowell (eds), Risks and Reconstruction: Experiences of Resettlers and Refugees (World Bank 2000) 5. 
There is widespread recognition that relocation should only occur with the free and informed consent of the communities concerned. This describes the process of finding out information about a proposed course of action and then weighing up the benefits and risks involved. Having accurate, up-to-date and culturally relevant information is essential. Affected communities should be fully informed of the reasons and procedures of movement, be able to propose alternatives to relocation that authorities 'should duly consider, ${ }^{34}$ and be compensated for any losses. ${ }^{35}$ If their consent cannot be obtained, then relocation should 'take place only following appropriate procedures established by national laws and regulations, including public inquiries where appropriate, which provide the opportunity for effective representation of the peoples concerned.' ${ }^{36}$

While consent is not the same as consultation and participation, these are necessary precursors to it. 'Consultation' refers broadly to the process of soliciting and listening to the opinions and perceptions of affected populations. 'Participation' implies a deeper engagement that may include control over decision-making. Both form part of a process in which key stakeholders influence and share control over initiatives and decisions that affect them. ${ }^{37}$ This can be best understood as a 'participation spectrum':

- Passive participation or information sharing in which the affected population is informed, but not heard (eg dissemination of documents or public briefings by officials).

34 Office of the High Commissioner for Human Rights, 'Basic Principles and Guidelines on DevelopmentBased Evictions and Displacement: Annex 1 of the Report of the Special Rapporteur on Adequate Housing as a Component of the Right to an Adequate Standard of Living' (2007) UN Doc A/HRC/4/18 para 38 (Basic Principles and Guidelines on Displacement).

35 United Nations High Commissioner for Refugees (UNHCR), 'United Nations Guiding Principles on Internal Displacement' (2001) UN Doc E/CN.4/1998/53/Add.2, principle 7(3); ILO Convention No 169 Concerning Indigenous and Tribal Peoples in Independent Countries (adopted 27 June 1989, entered into force 2 February 1995) 1650 UNTS 383, art 16(2) (ILO Convention No 169); United Nations Declaration on the Rights of Indigenous Peoples, UNGA Res 61/295 (7 September 2007) UN Doc A/61/L.67, art 10; Convention on Access to Information, Public Participation in Decision-Making and Access to Justice in Environmental Matters (adopted 25 June 1998, entered into force 30 October 2001) 2161 UNTS 447 (Aarhus Convention). Guidelines relating to safeguarding human rights in forced evictions are also relevant and practical: Basic Principles and Guidelines on Displacement (n 34) paras 56(e), 56(h), 56(i), 60. The Nansen Initiative's Draft Protection Agenda (n 7) para 65 notes that planned relocation processes must be implemented 'in full respect for the rights of affected people, including host communities, taking into account the potential of planned relocation to achieve development goals.'

36 ILO Convention No 169 (n 35) art 16(2). In the context of forced evictions, it is suggested that 'an independent body having constitutional authority, such as a court of law, tribunal or ombudsperson should mediate, arbitrate or adjudicate as appropriate': Basic Principles and Guidelines on Displacement (n 34) para 38.

37 Brookings-Bern Project on Internal Displacement, 'Moving Beyond Rhetoric: Consultation and Participation with Populations Displaced by Conflict or Natural Disasters' (October 2008) 4 <http:// www.brookings.edu/ /media/research/files/reports/2008/10/internal\%20displacement/10_internal_ displacement.pdf $>$ accessed 3 June 2015. See also Nansen Initiative Draft Protection Agenda (n 7) para 65, which notes the importance of '[e]ngaging both relocated and host communities in consultation, planning, implementation and evaluation of such measures, taking into account community ties, cultural values, traditions and psychological attachments to their original place of residence'. 
- Information transfer-affected populations supply information in response to questions but do not make decisions and do not influence the process. (This often takes the form of field visits and interviews.)

- Consultation-affected populations are asked to offer their opinions, suggestions, and perspectives but are not involved in decision-making or implementation of projects (and there is no guarantee that their views will influence the process.) Consultations can take multiple forms, including focus group discussions and interviews.

- Collaboration - the affected population is directly involved in needs analysis and project implementation. They may also contribute to agency-led projects with labor and other skills. (eg displaced persons supply labor for the construction of their new houses in an agency-sponsored project.)

- Decision making and control of resources-the affected populations are involved in project assessment, planning, evaluation and decision making. (This may involve, for example, a working group or joint-committee of agency and local leadership.)

- Local initiative and control-the affected populations take the initiative; the project is conceived and run by the community, potentially with the support of agencies (eg a community-based organization may organize professional training classes while receiving funding from another agency.) $)^{38}$

The extent to which local communities participate in the decisions about relocation and resettlement vary enormously. An example of a community-led initiative is in Alaska, where the Newtok Traditional Council has developed a detailed relocation plan with both short- and long-term objectives and projects (partly because there is insufficient funding to implement a single, streamlined plan). ${ }^{39}$ In 2009, the Council unanimously approved a set of guiding principles to underscore the relocation process. These outlined the community's desire to:

- Remain a distinct, unique community-our own community.

- Stay focused on our vision by taking small steps forward each day.

- Make decisions openly and as a community and look to elders for guidance.

- Build a healthy future for our youth.

- Our voice comes first-we have first and final say in making decisions and

- defining priorities.

- Share with and learn from our partners.

- No matter how long it takes, we will work together to provide support to our

- people in both Mertarvik and Newtok.

- Development should:

- Reflect our cultural traditions.

- Nurture our spiritual and physical wellbeing.

- Respect and enhance the environment.

- Be designed with local input from start to finish.

- Be affordable for our people.

38 Brookings-Bern Project on Internal Displacement (n 37) 4.

39 Robin Bronen, 'Climate-Induced Community Relocations: Creating an Adaptive Governance Framework based in Human Rights Doctrine’ (2011) 35 NYU Rev L and Soc Change 357, 388. 
- Hire community members first.

- Use what we have first and use available funds wisely.

- Look for projects that build on our talents and strengthen our economy. ${ }^{40}$

In order for there to be consent to relocation, consultative, participatory structures need to be in place to enable all sectors of the community to make informed choices, and to communicate these through a transparent process. ${ }^{41}$ For example, residents of Newtok undertook a relocation survey and voted in three separate processes about relocation options. ${ }^{42}$ As a small community of only 360 people, a detailed and individualised information-gathering process was possible. In larger communities, it is essential that all relevant agencies and community groups are identified so that fine-grained information can be fed through. For instance, in the Pacific, the importance of engaging churches, traditional leaders and civil society has been noted. ${ }^{43}$ In New Zealand, the government agency charged with overseeing recovery from the 2010-11 Christchurch earthquakes implemented a series of measures targeting different groups affected by the disaster, ranging from a telephone hotline, to community-wide informational sessions, to oneon-one sessions with individual homeowners. ${ }^{44}$

Prior to any decision on relocation being taken, there should be contingencies for different possible outcomes. For instance, will a majority decision in favour of relocation bind the community as a whole? Does it have to be a majority by a particular margin? What happens to those who have not consented if a majority has? ${ }^{45}$ Are there any alternatives to relocation?

\subsection{Timing: 'relocation' versus 'evacuation'}

The relationship between relocations and evacuations has generated considerable discussion, as noted above in describing the definitions developed at the Sanremo consultation. The argument made here is that the term 'planned relocations' should only refer to movement of people which is intended to be permanent, rather than to the often short-term movements made necessary by sudden-onset disasters.

40 Agnew Beck, Strategic Management Plan Newtok to Mertarvik (Anchorage 2012), cited in Bronen (n 23) 229.

41 For example, see abbreviated consultation procedures in World Bank Operations Manual (n 12).

42 See Arctic Slope Consulting Group, 'Newtok: Background for Relocation Report' (Newtok Traditional Council, January 2004) 15-20 <http://commerce.alaska.gov/dnn/Portals/4/pub/ NewtokBackgroundRelocation2004.pdf $>$ accessed 3 June 2015. See also app F (pros and cons of different relocation sites); app I (relocation survey documentation, including details of the voting process and detailed results).

43 Nansen Initiative Pacific Report (n 2) 27.

44 See Mitchell (n 24).

45 This may depend on the extent to which governments can compel people to move. For instance, in the United States, the government can enforce mandatory evacuation orders in a wide variety of disasters:

Thames Shipyard and Repair Co v United States, 350 F 4d 247 (2003). 
In contrast to a permanent relocation, an evacuation describes the temporary movement of people out of harm's way. While there are cases when evacuations become long-term (as in the case of those evacuated after the Fukushima nuclear disaster), the difference with relocations is that they were not planned, nor intended to be permanent. Many states have domestic laws authorising police or other authorities to forcibly evacuate people in emergencies, such as imminent natural disasters. ${ }^{46}$ Guidance on carrying out evacuations suggests that people should not be evacuated against their will unless this:

(a) Is provided for by law;

(b) Is absolutely necessary under the circumstances to respond to a serious and imminent threat to their life or health, and less intrusive measures would be insufficient to avert that threat; and

(c) Is, to the extent possible, carried out after the persons concerned have been informed and consulted. ${ }^{47}$

In all cases, people must be evacuated in a non-discriminatory manner that fully respects their rights to life, dignity, liberty and security. ${ }^{48}$

When it comes to evacuations in the event of disasters (either before or after they occur), the International Organization for Migration, through its leadership of the cluster on Camp Coordination and Camp Management, has worked with governments to develop a pilot manual on mass evacuations in natural disasters. ${ }^{49}$

While evacuation in the face of imminent harm is an accepted practice, relocation in anticipation of slow-onset hazards is more complex. The Chairman's Summary of the Nansen Conference on Climate Change and Displacement noted that 'moving communities in anticipation of climate-related hazards may precipitate vulnerability rather than avoiding it, and should only be considered when adequate alternatives that enable people to rebuild their lives is available. ${ }^{50}$

However, the Nansen Initiative has highlighted how 'proactive, pre-disaster' relocations can help to prevent future 'cross-border disaster-displacement, or dangerous,

46 See eg Amy L Fairchild, James Colgrove and Marian Moser Jones, 'The Challenge of Mandatory Evacuation: Providing for and Deciding for' (2006) 25 Health Aff 958.

47 Inter-Agency Standing Committee, 'IASC Operational Guidelines on the Protection of Persons in Situations of Natural Disasters' (Brookings-Bern Project on Internal Displacement, January 2011) principle A.1.4 $<$ https://docs.unocha.org/sites/dms/Documents/Operational\%20Guidelines.pdf > accessed 3 June 2015.

48 ibid principle A.1.5. See also International Law Commission, 'Protection of Persons in the Event of Disasters: Texts and Titles of the Draft Articles adopted by the Drafting Committee on First Reading' (15 May 2014) UN Doc A/CN.4/L.831, arts 5-8 (ILC Draft Articles).

49 See eg MEND Guide (n 16).

50 Chairperson's Summary, 'The Nansen Conference: Climate Change and Displacement in the 21st Century' (Oslo, 5-7 June 2011) para 12 (Nansen Conference) <http://www.unhcr.org/4ea969729.pdf> accessed 24 July 2015, drawing heavily on Jon Barnett and Michael Webber, 'Migration as Adaptation: Opportunities and Limits' in Jane McAdam (ed), Climate Change and Displacement: Multidisciplinary Perspectives (Hart Publishing 2010) 53. 
undocumented migration that could arise in the context of hardships associated with a disaster. ${ }^{51}$

\section{4 'Group' versus 'community'}

Whereas evacuations generally apply to individuals in a given geographic area at a particular moment in time-and can include tourists or visitors who happen to be caught in a disaster or emergency-the planned, permanent resettlement of groups tends to be associated with the movement of an identifiable community from one place to another. ${ }^{52}$ In contrast to the displacement or migration of individuals, it implies the movement of a group, usually with some kind of administrative or organisational structure that is to be recreated (in some form) in the new site. ${ }^{53}$

Campbell describes this process as:

the permanent (or long-term) movement of a community (or a significant part of it) from one location to another, in which important characteristics of the original community, including its social structures, legal and political systems, cultural characteristics and worldviews, are retained: the community stays together at the destination in a social form that is similar to the community of origin. ${ }^{54}$

Although it is possible to catalogue the issues that require careful consideration prior to any move, the longer-term impact of relocation on a particular community cannot be predicted. For instance, a 1977 study of ten relocated communities in the Pacific showed that resettlement outcomes could be entirely different, notwithstanding very similar conditions and macro relationships. ${ }^{55}$

Past experiences in the Pacific reveal the potentially deep, inter-generational psychological consequences of planned relocation and resettlement, ${ }^{56}$ which may explain why it is considered an option of last resort in that region. According to Connell, wherever relocation has occurred in the Pacific, social tensions have followed. ${ }^{57}$ Typically, this has been expressed through local opposition and resentment towards the relocated group,

51 Nansen Initiative Draft Protection Agenda (n 7) para 38.

52 Michael D Lieber, 'Conclusion: The Resettled Community and its Context' in Michael D Lieber (ed), Exiles and Migrants in Oceania (University Press of Hawaii 1977) 342.

53 Note, however, that there may be cases in the future where communities need to be relocated but there is insufficient land to resettle them all permanently as a community, and they may need to be dispersed across various sites.

54 John Campbell, 'Climate-Induced Community Relocation in the Pacific: The Meaning and Importance of Land' in Jane McAdam (ed), Climate Change and Displacement: Multidisciplinary Perspectives (Hart Publishing 2010) 58-59. Of course, over time, that original community may splinter and new groups may emerge.

55 Martin G Silverman, 'Introduction: Locating Relocation in Oceania' in Michael D Lieber (ed), Exiles and Migrants in Oceania (University Press of Hawaii 1977) 2-3; Lieber (n 52) 350.

56 McAdam, 'Historical Cross-Border Relocations in the Pacific' (n 8); Nansen Initiative Pacific Report (n 2) 15 , drawing on the views of Pacific representatives.

57 Connell (n 31) 138. 
with particular concerns about access to land, resources (such as food, water, education and healthcare) and jobs. ${ }^{58}$ While this has been especially marked when resettlement has occurred across cultural boundaries (including internal boundaries), ${ }^{59}$ even land transfers within a single cultural area have proven to be 'complex and challenging. ${ }^{60}$ This is why Pacific Islanders have emphasised the importance of learning lessons from past experience to inform future responses and policies. ${ }^{61}$

\section{5 'Relocation' versus 'resettlement'}

As noted at the outset of this article, planned relocation refers to the physical movement of people. With respect to planned relocations, however, simply transporting people to a new location will not be a sufficient response. Rather, resettlement-in the sense of recreating the community and re-establishing (or, better still, improving) social and economic conditions which existed prior to the relocation-is an essential complementary action. This is true in the context of climate change as well as in other cases, such as urban renewal schemes or resettlement of communities made necessary by suddenonset disasters that are not related to climate change, such as volcanoes or earthquakes.

Resettlement, as evidenced by the long experience of resettling communities in the context of development projects, is a much more complex and costly process than arranging for the physical movement of communities alone. Essential to the resettlement process is finding suitable land for the community, which includes tasks such as finding comparable land, judging it as acceptable, and paying for it. Land issues raise a host of difficult questions, particularly in cases where land ownership is either customary or communal, or both. ${ }^{62}$ Indeed, difficulties in finding suitable land have been major impediments to previous resettlement efforts. For example, negotiations to acquire land for the resettlement from the Carteret Islands to Bougainville have dragged on for years. ${ }^{63}$ Some of the practical suggestions for acquiring land to be used to resettle people after disasters are provided in the UN-Habitat's Handbook on Land and Natural

58 ibid 135-37. For instance, many Solomon Islanders viewed Gilbertese settlers as having taken 'their' land and jobs. See Kennett E Knudson, 'Sydney Island, Titiana, and Kamaleai: Southern Gilbertese in the Phoenix and Solomon Islands' in Michael D Lieber (ed), Exiles and Migrants in Oceania (University Press of Hawaii 1977) 223, cited in Connell (n 31) 136.

59 Connell (n 31) 136.

60 ibid.

61 Nansen Initiative Pacific Report (n 2) 16.

62 Nansen Initiative on Disaster-Induced Cross-Border Displacement, 'Background Paper: "Human Mobility, Natural Disasters and Climate Change in the Pacific"' (Nansen Initiative Pacific Regional Consultation, Rarotonga, 21-24 May 2013) <http://www.nanseninitiative.org/pacific-consultations-intergovernmental/> accessed 24 July 2015. See also Daniel Fitzpatrick and Rebecca Monson, 'Climate Change and the Legal Framework for Settlement Relocation in the South Pacific' (FIG Paper Pacific Small Island Developing States Symposium in Suva, Fiji,18-20 September 2013) <https://www.fig.net/resources/proceedings/2013/ fiji/papers/ts\%201b_daniel_6742.pdf> accessed 4 June 2015.

63 Campbell (n 54) 68-71; Connell (n 31). See also Bronen (n 23). 
Disasters. ${ }^{64}$ However, there are not many case studies of the process by which good resettlement plans have been implemented for people relocated in the aftermath of sudden-onset disasters. A collection of case studies from four Latin American countries of 'preventive resettlement' found that even when resettlement was carefully planned, land was acquired, and adequate funds were available, a major challenge was to prevent (poor) people from settling on the land vacated by those who were resettled. ${ }^{65}$

In addition to securing suitable land, major difficulties have been encountered in reestablishing sustainable livelihoods for people relocated after disasters as well as provision of necessary infrastructure and access to public services. In planning resettlement, the experiences of the multilateral development banks in working with those resettled as a result of development projects may be particularly useful. ${ }^{66}$

The basic principles on which existing guidelines for development-induced displacement and resettlement (DIDR) are based can be summed up in a few sentences. Involuntary resettlement should be avoided where feasible. ${ }^{67}$ Where it is not feasible to avoid resettlement, the scale of displacement should be minimised and resettlement activities should be conceived and executed as sustainable development programmes based on meaningful consultation with displaced persons. Displaced persons should be assisted to improve their livelihoods and living standards at least to the levels they enjoyed before the displacement. ${ }^{6}$

People who are forcibly relocated by development projects, and hence considered to be displaced, risk a sharp decline in their standards of living. Michael Cernea's impoverishment and reconstruction model, which is discussed in more detail below, identifies the common risks of such displacement: landlessness, joblessness, homelessness, marginalisation, food insecurity, increased morbidity and mortality, loss of access to common property, and social disintegration. ${ }^{69}$ If left unaddressed, these embedded risks result in massive impoverishment. Particular groups may be especially

64 United Nations Human Settlements Programme, 'Land and Natural Disasters: Guidance for Practitioners' (2010) <http://disasterassessment.org/documents/land_and_natural_disasters_guidance4practitioners.pdf> accessed 4 June 2015. See also Ian Christoplos and others, 'Learning from Recovery after Hurricane Mitch: Experience from Nicaragua' (International Federation of Red Cross and Red Crescent Societies and ProVention Consortium 2009) <http://www.recoveryplatform.org/assets/publication/Learning_from_ Mitch_summary.pdf> accessed 3 June 2015.

65 Daniel Fitzpatrick, 'Housing for the Landless: Resettlement in Tsunami-Affected Aceh, Indonesia' (2007) Asia Research Institute and Oxfam International Aceh Working Paper No 1, <http://www.ari.nus.edu.sg/ docs/downloads/aceh-wp/acehwps07_001.pdf> accessed 3 June 2015; Elena Correa, 'Resettlement as a Disaster Risk Reduction Measure: Case Studies' in Elena Correa (ed), Preventive Resettlement of Populations at Risk of Disaster: Experiences from Latin America (World Bank Global Facility for Disaster Reduction and Recovery 2011) 19 <http://www.gfdrr.org/sites/gfdrr.org/files/preventive_resettlement_LAC_experiences. pdf $>$ accessed 3 June 2015.

66 World Bank Operations Manual (n 12).

67 Some forms of DIDR may be forced, and the term 'development-forced displacement and resettlement' (DFDR) is consequently used by many working in the field.

68 World Bank Operations Manual (n 12) para 15.

69 Michael M Cernea, 'Risks, Safeguards, and Reconstruction: A Model for Population Displacement and Resettlement' in Michael M Cernea and Christopher McDowell (eds), Risks and Reconstruction: Experiences 
affected, as noted in the World Bank's Operational Manual: 'Bank experience has shown that resettlement of indigenous people with traditional land-based modes of production is particularly complex and may have significant adverse impacts on their identity and cultural survival. ${ }^{70}$

\subsection{Relocation as adaptation}

The 1992 United Nations Framework Convention on Climate Change begins by noting that the 'ultimate objective of this Convention (...) is to achieve (...) stabilization of greenhouse gas concentrations in the atmosphere at a level that would prevent dangerous anthropogenic interference with the climate system' (article 2), but article 4(1) goes on to make the case that adaptation measures, as well as mitigation, are needed.

The need for the development of national adaptation plans was reaffirmed in the 1997 Kyoto Protocol (articles 10 and 12), and the Conference of the Parties (COP 7) at Marrakesh highlighted the importance of developing a national action plan based on assessments and evaluations. The 2009 Copenhagen Accord set up a Green Climate Fund, including a fast-start finance fund approaching \$30 billion for 2010-12 to be followed by a fund of $\$ 100$ billion in 2020 for both adaptation and mitigation.

Since the beginning of international discussions on climate change, the issue of funding of adaptation measures has been a central and contentious point of discussion and a complex array of international adaptation funding mechanisms now exist.

Despite the emphasis on climate change adaptation funds in the framework of the international climate change negotiations, it has proven difficult for many states to access adaptation funding ${ }^{71}$-and perhaps just as difficult for donors to ensure that the funds pledged do in fact materialise. ${ }^{72}$ The fact that there is an eight-year gap between the pledges of $\$ 30$ billion from $2010-12$, to $\$ 100$ billion per year beginning in 2020, is an indication of the likely difficulties in funding adaptation strategies.

As mentioned above, the Cancún COP 16 meeting called on states to develop national adaptation plans (NAPs), building on earlier work to support the development of NAPAs. The fact that very few governments included migration, displacement and relocation in the NAPAs - and that migration and relocation are not mentioned at all in the technical guidelines ${ }^{73}$-is perhaps a sign that states have not yet properly considered

of Resettlers and Refugees (World Bank 2000); Michael Cernea, 'Public Policy Responses to DevelopmentInduced Population Displacements' (1996) 31 Eco \& Pol Wkly 1515.

70 World Bank Operations Manual (n 12) para 9.

71 Mary Jane Mace, 'Funding for Adaptation to Climate Change: UNFCCC and GEF Developments since COP-7’ (2005) 14 Rev of Eurpn Comm \& Intl Enviro Law 225.

72 See eg 'Aid Policy: Climate Change and Adaptation Funding Equally Unpredictable' (IRIN News, 11 February 2010) <http://www.irinnews.org/report/88070/aid-policy-climate-change-and-adaptationfunding-equally-unpredictable $>$ accessed 3 June 2015.

73 While displacement is mentioned, it is in the context of assessing the potential impact of climate change on the country. 
mobility as a form of adaptation to climate change. And yet, one of the principal lessons learned from past relocations and resettlements is the need for planning, which requires a long lead time.

With respect to planning, the Nansen Initiative has identified a number of 'effective practices', which include (inter alia):

- Identifying and setting aside land for temporary and permanent relocation as a disaster preparedness activity;

- Developing national and local level guidelines and public policies to support effective and sustainable planned relocation processes, adapted to the local context and building upon existing global guidance;

- Ensuring that planned relocation sites do not expose relocated people to greater disaster risks and provide for disaster risk management measures in the event of future disasters; and

- Developing adequate mechanisms and safeguards to prevent and solve conflicts over land and other resources due to factors such as cultural diversity or population growth. ${ }^{74}$

It may well be that some governments are unwilling to consider relocation-or any form of mobility-as an adaptation measure because of a fear that by doing so, they will be seen by their populations as having 'given up' on mitigation measures. Sometimes, past poor experiences of relocation may impede the government's willingness to view it as a suitable future policy option. For instance, in Bangladesh, the state-driven resettlement of up to 600,000 Bengali settlers into the Chittagong Hill Tracts during military rule in Bangladesh provoked violence which was only settled by a Peace Accord in 1997 (although unrest continues). ${ }^{75}$ The government remains wary of repeating the mistake, and there is accordingly a sense among some officials that movement should be a matter of individual choice rather than dictated by state policy. ${ }^{76}$

While migration experts recognise that movement away from vulnerable areas can be a form of adaptation by facilitating livelihoods elsewhere, stimulating the flow of remittances and helping to alleviate pressure in the community of origin, the reality seems to be that the process of deciding to move is a complex one. A recent study by Koko Warner and others showed that when it comes to individual/household migration, some people will move as an adaptation strategy to enhance their resilience to climate change, while more vulnerable groups will use it merely 'to survive, but not flourish. ${ }^{77}$

74 Nansen Initiative Draft Protection Agenda (n 7) para 65. See also the Draft Guidance on Protecting People through Planned Relocations, developed at the May 2015 Bellagio Consultation (n 6) which provides extensive guidance on the planning process when relocations are considered.

75 Chittagong Hill Tracts Accord (Chittagong Hill Tracts-Bangladesh) (adopted 2 December 1997) <http:// www.chtdf.org/index.php/cht-issues/peace-accord> accessed 24 July 2015.

76 Jane McAdam and Ben Saul, 'Displacement with Dignity: International Law and Policy Responses to Climate Change Migration and Security in Bangladesh' (2010) 53 Germ Yrbk Intl L 233, 276, referring to an interview with SM Munjurul Hannan Khan, Deputy Secretary, Ministry of Environment and Forests and National Focal Point for the UNFCCC and IPCC, Bangladesh (Dhaka, 15 June 2010).

77 Koko Warner and Tamer Afifi, 'Human Migration: Patterns and Emerging Understanding' in Koko Warner and others (eds), Changing Climates, Moving People: Framing Migration, Displacement and Planned Relocation (2013) UN University Policy Brief No 8, 21. 
Similarly, the Foresight report concluded that some people seem to be moving from areas that are less vulnerable to the effects of climate change towards areas that are more vulnerable (particularly cities which are more vulnerable to disasters), suggesting that mobility may not always be adaptive-but rather can be maladaptive as well-a theme also picked up by Barnett and O'Neill. ${ }^{78}$

Sou's research on post-disaster resettlement in urban Bolivia shows how ill-conceived relocation schemes can 'leave people living in uncomfortable and precarious living conditions which increase their vulnerability. ${ }^{79}$ She attributes part of the problem to 'a reductive understanding of human behaviour that (...) does not account for the many reasons why people choose to live in "risky" areas, nor (...) the indirect and detrimental effects that resettlement can have on people who choose to stay put. ${ }^{80}$ Thomas' analysis of post-disaster resettlement in the Philippines reveals similar problems. She argues that 'insufficient advance planning and slow implementation' have not only prolonged displacement, but have also potentially increased the vulnerability of hundreds of thousands of people, many of whom are poor and landless. ${ }^{81}$

Forward-planning by states is crucial, since the mechanisms they put in place will be key to determining the extent to which relocation can be utilised as a form of adaptation, rather than signalling a failure to adapt. ${ }^{82}$ Planned relocations, it is argued here, can be a form of adaptation to climate change, and states likely to be affected by climate change should be encouraged to consider: (a) the extent to which relocations might be necessary; (b) under what conditions they might need to occur; (c) under what modalities they might occur; and (d) their possible costs. Given that planned relocations have a long history in relationship to development projects, this would seem to be an area where development actors could play a supportive role.

Central to the issue of adaptation strategies is the question of who should pay. Significantly, the Cancún Adaptation Framework recognises migration as a form of adaptation, and this means that international adaptation funding may be directed towards preventing displacement and developing relocation and migration schemes. Indeed, funding relocation through international mechanisms may be one of the main ways in which the international community can play a meaningful role in addressing climate change and disaster-related movement. In fact, the Nansen Initiative consultation

Government Office for Science (n 18); Barnett and O’Neill (n 25); Jon Barnett, 'On the Risks of Engineering Mobility to Reduce Vulnerability to Climate Change: Insights from a Small Island State' in Kirsten Hastrup and Karen Fog Olwig (eds), Climate Change and Human Mobility: Global Challenges to the Social Sciences (CUP 2012) 169.

79 Gemma Sou, 'Post-Disaster Resettlement in Urban Bolivia' (2015) 49 Forced Migration Rev 33, 33.

80 ibid 34.

81 Alice R Thomas, 'Post-Disaster Resettlement in the Philippines: A Risky Strategy' (2015) 49 Forced Migration Rev 52, 52.

82 Koko Warner, 'Assessing Institutional and Governance Needs Related to Environmental Change and Human Migration' (Study Team on Climate Induced Migration, Climate Change and Migration, June 2010) 8 <http://archive.unu.edu/africa/activities/files/Warner_K_2010_Assessing_Institutional_and_ Governance_Needs_Related_to_Environmental_Change.pdf> accessed 24 July 2015. 
identified this-rather than the creation of new legal frameworks-as one of the areas where meaningful international cooperation could be useful. ${ }^{83}$ But, as yet, there is no clear guidance from the many adaptation funds enumerated above about how their resources can be used to support migration, displacement and planned relocations as adaptation strategies. For example, can adaptation funds be envisaged to pay for physical elements of relocation and resettlement expenses to ensure that livelihoods/services are restored, and also for compensation/restitution? Can adaptation funds be used to support planning, including consultations with communities likely to be affected, for relocations?

\section{Policy challenges}

\subsection{On what basis are decisions made? Data}

The question of what data will be relied upon to make decisions about planned relocations raises a host of complex issues. How will a state determine that an area is uninhabitable and that communities must be moved? For example, the absence of a sustainable fresh water supply is expected to render some Pacific Island countries uninhabitable long before they are submerged by rising seas. ${ }^{84}$ What indicators should be used to determine that an area is uninhabitable? When fresh water supplies are unavailable for a significant proportion of the population? When agricultural production is no longer viable? When livelihoods are no longer feasible? When coastlines become increasingly battered by storms and water intrusion? The involvement of the scientific community would seem to be essential in determining that an area is uninhabitable and that its inhabitants should therefore be relocated.

Consideration must also be given to the relationship between these indicators and the coping capacity of the population. For instance, a given area may be uninhabitable for the present population but may be habitable for a smaller population. Thus, a decision to relocate only a portion of the population may be a legitimate response to the pressures of climate change. However, this raises a host of other questions, particularly if some of the population to be moved would rather remain and conversely if those slated to remain would rather be relocated. There are also questions about the extent to which a minimum population is necessary below which life becomes unsustainable-a question raised by Jon Barnett in the case of Niue. ${ }^{85}$

A second issue relating to data is that of trust in the competent authorities who make the decision. The UN Guiding Principles on Internal Displacement emphasise that such decisions must be made by competent authorities on the basis of law, in consultation

83 Nansen Initiative Pacific Report (n 2) 18.

84 Nurse and others (n 17) ch 29; McAdam, Climate Change, Forced Migration, and International Law (n 4) 124, 131.

85 Barnett and O’Neill (n 25). 
with affected communities. ${ }^{86}$ Even when governments have been elected through democratic means, building and sustaining trust with the community is essential. Simply put, if people do not trust the government, then they are likely to be sceptical about any governmental decision that requires them to move. For example, there may be a perception that governments are more responsive to business interests than to those actually living in a given community, or there may be suspicions that governments have ulterior motives in wanting people to move off a particular piece of land. ${ }^{87}$

A third area of difficulty concerns the extent to which an area's uninhabitability is due to the effects of climate change rather than other factors, such as (human-caused) deforestation. As noted above, it is impossible to isolate climate change as the sole cause of displacement; it will always result from a combination of factors that interact with each other in different ways in different contexts. However, if financing for relocation is to be secured through dedicated climate change adaptation funds, then the link between the need for relocation and climate change needs to be clear. In cases where the causal relationship is not straightforward, the spectre arises of negotiations to determine the percentage of uninhabitability due to climate change and the percentage attributable to other factors. As McAdam has argued, this may shift the focus away from the need to protect those at risk to a scientific determination that is likely impossible to make. ${ }^{88}$

A fourth area of difficulty concerns 'counting' the number of people to be relocated. No existing legal or bureaucratic categories 'count' those who move in response to the impacts of climate change. This means that even where climate change plays a role in mobility decisions, it will not necessarily be understood as 'climate change' migration/ displacement/relocation. Accordingly, the data on such movement is also fraught with methodological problems. ${ }^{89}$ Which groups should be included in such an enumerationjust those that are assisted to relocate, or those that relocate on their own to the new resettlement site, or those that choose to move elsewhere because they do not like the alternative? Some of the development-related resettlement guidelines on determining eligibility for compensation might be relevant in this regard. ${ }^{90}$ For example, is someone who moved into the area the year before-or the week before-entitled to the same level of relocation assistance as someone who has lived there all his/her life?

86 UN Guiding Principles on Internal Displacement (n 35).

87 See eg Ferris (n 24) 34, referring to Michael M Cernea and Hari Mohan Mathur, 'Compensation and Investment in Resettlement: Theory, Practice, Pitfalls, and Needed Policy Reform' in Michael M Cernea and Hari Mohan Mathur (eds), Can Compensation Prevent Impoverishment? Reforming Resettlement through Investments and Benefit-Sharing (OUP 2008) 15; Thayer Scudder, The Future of Large Dams: Dealing with Social, Environmental, Institutional and Political Costs (Earthscan 2005) 53. Even in colonial times, relocation was not just 'a function of the colonial administration's perception of an impending emergency', but was also related to the administration's plans for 'ethnic integration of larger administrative districts': Lieber (n 52) 346.

88 McAdam, Climate Change, Forced Migration, and International Law (n 4) 196-97.

89 ibid 24ff, 36ff.

90 See eg World Bank Operations Manual (n 12). 


\subsection{Legal bases for decisions}

States bear the primary responsibility under international law to ensure that the human rights of those within their territory or jurisdiction are respected. This includes the obligation to take preventative as well as remedial actions to uphold such rights, and to assist those whose rights have been violated. ${ }^{91}$

In 2014, the International Law Commission adopted draft articles on the protection of persons in the event of disasters. ${ }^{92}$ These provide that states have a duty to reduce disaster risk 'by taking the necessary and appropriate measures, including through legislation and regulations, to prevent, mitigate, and prepare for disasters. ${ }^{93}$ If a disaster overwhelms a state's national response capacity, then the state has a duty to seek assistance from other states, international organisations or NGOs. ${ }^{94}$ All disaster-related responses should be underpinned by the principles of dignity, cooperation, humanity, neutrality and impartiality, and '[p] ersons affected by disasters are entitled to respect for their human rights. ${ }^{95}$

In some cases, states' obligations to take preventative measures to safeguard life, physical integrity, health and so on may require the relocation of individuals or groups out of harm's way. Whereas this would ordinarily constitute arbitrary displacement, it may be justified if there is no other viable alternative and it is necessary to safeguard 'the safety and health of those affected. ${ }^{96}$ For instance, the European Court of Human Rights has recognised that environmental damage can affect the rights to life, property, home, and private life, ${ }^{97}$ and, as such, a state's obligation to protect the right to life may also include protection from environmental harm. ${ }^{98}$ In Budayeva $v$ Russia, the court held that this duty encompassed an obligation to protect communities from foreseeable natural disasters, which included informing the population about possible dangers and risks, evacuating potentially affected populations, and compensating surviving relatives of victims killed as a consequence of neglecting these duties. ${ }^{99}$

91 International Covenant on Civil and Political Rights (adopted 16 December 1966, entered into force 26 March 1976) 999 UNTS 171, art 2; Inter-American Court of Human Rights Velasquez Rodriguez v Honduras (1988) 28 ILM 291, paras 174-75.

92 See ILC Draft Articles ( $\mathrm{n}$ 48). The ILC is the international body responsible for the progressive development and codification of international law. The draft articles are currently with governments and international organisations for comment by 1 January 2016.

93 ibid art 11. See also Nansen Principle II, in Nansen Conference (n 50) 5.

94 ILC Draft Articles (n 48) art 13.

95 ibid arts 5-8.

96 UN Guiding Principles on Internal Displacement (n 35) principle 6(2)(d).

97 See cases cited in Loukis G Loucaides, The European Convention on Human Rights: Collected Essays (Martinus Nijhoff 2007) ch 10, including Arrondelle v United Kingdom (1980) 19 DR 186 (noise pollution cases offensive smells); Sergio Euben Lopez Burgos v Uruguay (29 July 1981) Comm No R.12/52, Supp No 40, UN Doc A/36/40 176; Guerra v Italy (1998) 26 EHRR 357; Fadeyeva v Russia (2007) 45 EHRR 10.

98 See Öneryildiz v Turkey (2005) 41 EHRR 20, paras 71-72.

99 Budayeva $v$ Russia App nos 15339/02, 21166/02, 20058/02, 11673/02, 15343/02 (ECtHR, 20 March 2008). See further Walter Kälin and Claudine Haenni Dale, 'Disaster Risk Mitigation: Why Human Rights Matter' (2012) 31 Forced Migration Rev 38, 39; Elizabeth Ferris, 'How Can International Human Rights 
It is widely acknowledged that most movement stimulated by environmental conditions (including climate change) will take place within countries, rather than across international borders. ${ }^{100}$ Accordingly, internal movements, including relocations, will be governed by domestic laws. Of course, these must comply with international human rights law and other applicable international law norms (in cases of conflict, for example, this will include international humanitarian law), both in substance and in practice. Many of the relevant international legal principles have been identified in the preceding discussion, and are synthesised in the UN Guiding Principles on Internal Displacement. ${ }^{101}$ Ferris has also compiled a list of Preliminary Understandings for Planned Relocation of Populations as a Result of Climate Change, which draws out particular additional considerations in the context of relocation and climate change. ${ }^{102}$

Since relocation has implications for a whole range of rights-civil, political, economic, social and cultural-it necessarily concerns a wide range of domestic laws relating to such apparently disparate issues as land, housing, property, insurance, employment, anti-discrimination, minorities, restitution, and so on. Laws relating to evictions, for instance, may be highly relevant. ${ }^{103}$ Using Cernea's 'impoverishment hazards' tool, one can identify the kinds of domestic laws that will be relevant. ${ }^{104}$

As can be seen from Table 1, civil and political rights intersect with socio-economic and cultural rights, and indeed the enjoyment of one may be contingent on another. Further, having secure access to shelter and employment is likely to enhance food security and health, whereas homelessness and unemployment will increase further

Law Protect us from Disasters?' (Paper prepared for the American Society of International Law, Annual Meeting, 10 April 2014) <http://www.brookings.edu/ /media/Research/Files/Papers/2014/04/22\%20 natural\%20disasters\%20ferris/EFerris\%20ASIL\%20Human\%20Rights\%20and\%20Disasters\%2020140410. pdf $>$ accessed 3 June 2015.

100 Government Office for Science (n 18) 37.

101 In contrast, the policies and principles developed to guide DFDR provide comprehensive operational guidance for relocations and resettlement: see particularly World Bank Operations Manual (n 12). Whereas the focus of the UN Guiding Principles on Internal Displacement (n 35) is upholding the rights of the displaced, the focus of the Operational Policy is preventing the impoverishment of those who move. See also Scott Leckie, 'Climate-Related Disasters and Displacement: Homes for Lost Homes, Lands for Lost Lands' in Jose Guzman and others (eds), Population Dynamics and Climate Change (International Institute for Environment and Development, UNFPA 2009) 119; Michael Cernea, 'Understanding and Preventing Impoverishment from Displacement' in Chris McDowell (ed), Understanding Impoverishment: The Consequences of Development-Induced Displacement (Berghahn Books 1996) vol 2, 13.

102 Ferris (n 11) 26-30. Further guidance is provided by the Draft Guidance on Protecting People through Planned Relocations, developed at the May 2015 Bellagio Consultation (n 6).

103 See eg Jean du Plessis, 'Olympic Scale of Sport-Induced Displacement' (2007) 28 Forced Migration Rev 54. See also Mariya Gromilova, 'Revisiting Planned Relocation as a Climate Change Adaptation Strategy: The Added Value of a Human Rights-Based Approach' (2014) 10(1) Utrecht L Rev 76 for a broad application of a rights-based approach for those facing relocations.

104 Michael M Cernea, 'Impoverishment Risks, Risk Management, and Reconstruction: A Model of Population Displacement and Resettlement' (UN Symposium on Hydropower and Sustainable Development, Beijing, 27-29 October 2013) <http://www.un.org/esa/sustdev/sdissues/energy/op/hydro_cernea_population_ resettlement_backgroundpaper.pdf $>$ accessed 4 June 2015. See also the discussion of applicable laws in McAdam and Saul (n 76). 
Table 1

\begin{tabular}{|c|c|c|c|}
\hline Risk & Reconstruction & Relevant areas of law & Key government agencies \\
\hline Landlessness & $\begin{array}{l}\text { Land-based } \\
\text { reestablishment }\end{array}$ & $\begin{array}{l}\text { Land law, property law, } \\
\text { anti-discrimination } \\
\text { law, restitution, labour } \\
\text { law, environmental law, } \\
\text { disaster law }\end{array}$ & $\begin{array}{l}\text { Land management } \\
\text { agencies; interior } \\
\text { ministry; environment } \\
\text { ministry }\end{array}$ \\
\hline Joblessness & Re-employment & $\begin{array}{l}\text { Labour law, anti- } \\
\text { discrimination law, } \\
\text { land law, property law, } \\
\text { education }\end{array}$ & $\begin{array}{l}\text { Labour ministry; labour } \\
\text { unions }\end{array}$ \\
\hline $\begin{array}{l}\text { Homelessness } \\
\text { (which may } \\
\text { include loss of } \\
\text { 'cultural space') }\end{array}$ & $\begin{array}{l}\text { House } \\
\text { reconstruction }\end{array}$ & $\begin{array}{l}\text { Property law, planning } \\
\text { law, housing law, law } \\
\text { relating to evictions, } \\
\text { anti-discrimination law, } \\
\text { restitution, insurance law, } \\
\text { disaster law }\end{array}$ & $\begin{array}{l}\text { Housing ministry; urban } \\
\text { planning/agriculture } \\
\text { ministry }\end{array}$ \\
\hline Marginalisation & Social inclusion & $\begin{array}{l}\text { Anti-discrimination law, } \\
\text { law relating to minorities, } \\
\text { labour law, land law, } \\
\text { property law, education, } \\
\text { freedom of religion, } \\
\text { voting rights }\end{array}$ & $\begin{array}{l}\text { National human rights } \\
\text { institutions; justice } \\
\text { ministry; specific agencies } \\
\text { charged with working on } \\
\text { minority issues }\end{array}$ \\
\hline Food insecurity & Adequate nutrition & $\begin{array}{l}\text { Agricultural law, access } \\
\text { to services, access to } \\
\text { distribution networks, } \\
\text { anti-discrimination law, } \\
\text { labour law, land law, } \\
\text { property law, disaster law }\end{array}$ & $\begin{array}{l}\text { Food/agriculture } \\
\text { ministry; environment } \\
\text { ministry }\end{array}$ \\
\hline $\begin{array}{l}\text { Increased } \\
\text { morbidity and } \\
\text { mortality }\end{array}$ & Better health care & $\begin{array}{l}\text { Health law (including for } \\
\text { children), land law, labour } \\
\text { law, anti-discrimination } \\
\text { law }\end{array}$ & $\begin{array}{l}\text { Health ministry and } \\
\text { related agencies }\end{array}$ \\
\hline $\begin{array}{l}\text { Loss of access to } \\
\text { common property } \\
\text { and services }\end{array}$ & $\begin{array}{l}\text { Restoration of } \\
\text { community assets } \\
\text { and services }\end{array}$ & $\begin{array}{l}\text { Restitution, property law, } \\
\text { anti-discrimination law, } \\
\text { land law }\end{array}$ & $\begin{array}{l}\text { Justice ministry and other } \\
\text { related ministries }\end{array}$ \\
\hline $\begin{array}{l}\text { Social } \\
\text { disarticulation }\end{array}$ & $\begin{array}{l}\text { Community } \\
\text { reconstruction }\end{array}$ & $\begin{array}{l}\text { Protection of family and } \\
\text { private life, law relating } \\
\text { to minorities, protection } \\
\text { of cultural heritage } \\
\text { (including language), } \\
\text { anti-discrimination law, } \\
\text { education, freedom of } \\
\text { religion, freedom of } \\
\text { association, marriage law, } \\
\text { land law }\end{array}$ & $\begin{array}{l}\text { Justice ministry; } \\
\text { ministries concerned with } \\
\text { social welfare; ministries } \\
\text { concerned with cultural } \\
\text { heritage }\end{array}$ \\
\hline
\end{tabular}


marginalisation in other areas. This is why 'labour law' is also relevant to 'health', and why comprehensive resettlement planning requires the engagement of different government agencies and relevant civil society organisations.

As yet, there has been no systematic analysis of state practice relating to relocations and the legal issues involved. ${ }^{105}$ This has been identified as an important area for future research. ${ }^{106}$ At present, the legal framework for decisions about relocations varies from state to state, and very few states have developed laws or policies relating specifically to relocations made necessary by the effects of climate change. ${ }^{107}$ In some countries, constitutional provisions may restrict the state's ability to relocate specific communities, such as indigenous groups. Existing laws and policies from the context of developmentforced displacement and resettlement may provide some general guidance, as may national policies on eminent domain, evictions, and natural disasters. ${ }^{108}$ But even where legal guidance exists, it requires implementation and enforcement to be effective.

The Nansen Initiative on Disaster-Induced Cross-Border Displacement's 2013 Report on the Pacific concluded that '[e]xisting guidelines are insufficient for effectively planning and implementing planned relocation in the context of disasters', and that:

[n]ational authorities should consider developing relocation guidelines that are consistent with relevant international resettlement standards (eg SPHERE, World Bank), incorporate alternative or innovative adaptation measures, and take into account customary land tenure systems. ${ }^{109}$

A review of a number of the Pacific's national disaster risk reduction and climate change adaptation policies and planning instruments 'shows weak, almost non-existent reference or inclusion of human mobility challenges in the context of natural disasters and climate change (eg displacement, relocation, evacuation, protection, etc). ${ }^{110}$

There will usually be different decision-making structures in place depending on whether a movement is conceived of as a temporary 'evacuation' or a permanent 'relocation'. For example, the police and emergency services may have extensive powers during sudden-onset events such as cyclones, and are often key actors in evacuating people. However, they are not the appropriate actors to be making decisions for planned relocations, especially where these are envisaged as permanent. In some African countries like Uganda, district disaster commissioners make many of these decisions, but when situations become hot political issues, the national government takes over.

105 Ferris (n 11) 32.

106 See eg Sanremo Report (n 6); Global Knowledge Partnership on Migration and Development (KNOMAD), Thematic Working Group on Migration and Environmental Change: Symposium Report (14-15 May 2014) (forthcoming).

107 Fitzpatrick and Monson (n 62); Sanremo Report (n 6).

108 See International Federation of Red Cross and Red Crescent Societies, 'Disaster Law Database' <https:// ifrc.org/en/publications/disaster-law-database/> accessed 16 July 2015.

109 Nansen Initiative Pacific Report (n 2) 21.

110 ibid 25. 
While in many cases the 'state' makes the decision and engineers the relocation, it is important to remember that states are not monolithic creatures. ${ }^{111}$ Indeed, there is a striking lack of coordination between government agencies and departments, and across different levels of government. To ensure that all the rights of relocating communities are addressed, a whole-of-government approach is not only desirable, but necessary. This requires coordination across different government departments as well as different government levels (local, provincial, and national), and the cooperation of various operational agencies. ${ }^{112}$ As stated in Nansen Principle X, policies relating to planned relocation must 'be implemented on the basis of non-discrimination, consent, empowerment, participation and partnerships with those directly affected, with due sensitivity to age, gender and diversity aspects. ${ }^{113}$

\subsection{Specific legal issues for cross-border relocations}

There are very few instances of cross-border relocations of whole communities, and most of these relate to Pacific examples: the Gilbertese movement to the Solomon Islands between 1955 and 1964 (via the Phoenix Islands from 1937); the relocation of the Banabans from present-day Kiribati to Rabi in Fiji in 1945; and the relocation of a group of Vaitupuans from present-day Tuvalu to Kioa in Fiji from 1947 (the latter two discussed above). In 1856, the whole population of Pitcairn Island (around 200 people) was resettled on Norfolk Island, some 6,000 kilometres away. ${ }^{114}$ Historical records reveal that the Western Pacific High Commissioner, who governed, inter alia, present-day Kiribati and Tuvalu until the 1970s, actively sought to resettle communities on account of land shortages, but struggled to find available land. ${ }^{115}$

While the international relocation of whole Pacific Island communities has been mooted from time to time, there are no moves afoot to facilitate this. There is acknowledgement by Pacific leaders that the likelihood of any state ceding land to it is

111 See eg Mark Bevir and RAW Rhodes, The State as Cultural Practice (OUP 2010), where the authors coin the idea of the 'stateless state. For them, the state is neither monolithic nor a causal agent, but consists of the actions of specific individuals (such as civil servants and politicians). Reflecting on the collection Cris Shore, Susan Wright and Davide Però (eds), Policy Worlds: Anthropology and the Analysis of Contemporary Power (Berghahn Books 2011), Prince says that policy is conceived of as 'taking shape through the arrangement of people and things in relation to one another across space and time. Further, if we 'conceive of policy as assemblages or networks that take shape across social space the challenge becomes how to understand the way power works within these arrangements to make our critique': Russell Prince, 'Review Essay: Disaggregating the State: Exploring Interdisciplinary Possibilities for the Study of Policy' (2013) 34 Political Geography 60, 62.

112 See Nansen Principles III, IV, VI, in Nansen Conference (n 50) 5.

113 Nansen Principle X, in Nansen Conference (n 50) 5.

114 Connell (n 31) 127; McAdam, 'Historical Cross-Border Relocations in the Pacific' (n 8); Gil Marvel Tabucanon, 'The Banaban Resettlement: Implications for Pacific Environmental Migration' (2012) 35 Pacific Studies 343.

115 HE Maude, 'The Colonization of the Phoenix Islands' (1952) 61 J Polynesian Society 62; McAdam, 'Historical Cross-Border Relocations in the Pacific' (n 8). 
remote, and while Kiribati has purchased a tract of fertile church-owned land in Fiji, this is not (contrary to media reports) to secure a new homeland for the people of Kiribati, but rather to provide food security and possible employment opportunities for its citizens. ${ }^{116}$ There is a Pacific notion that blood and mud mix together to create identity. Most Pacific Islanders are resistant to group relocation because they perceive it as a permanent rupture with home, land and identity. ${ }^{117}$ They fear it may impact negatively on nationhood, control over land and sea, sovereignty, culture and livelihoods. ${ }^{118}$

Hence, in cases of cross-border relocations, additional issues may arise about the ongoing status of the group once it moves (for instance, whether it can retain statehood or acquire a self-governing status in the new territory-issues which remain under examination by international lawyers). ${ }^{119}$ Further, immigration and citizenship rights need to be negotiated. A recommendation from the Nansen Initiative's Pacific Consultations was that any planned relocation to another country should:

i) define the legal status of the relocated community within the new state, ii) help communities adapt to local customs and laws, iii) include consultation with potential host communities, and iv) contain measures to facilitate the diaspora community maintaining cultural ties, such as allowing dual citizenship. ${ }^{120}$

Even these measures provide no guarantee that the relocated group will simply 'assimilate'; as the example of the Banabans in Fiji shows, innovative inter-generational constitutional protections of rights to land and nationality may not overcome feelings of disenfranchisement, dislocation and displacement. ${ }^{121}$ This is because permanent relocation can have highly pragmatic and deeply spiritual ramifications for the community concerned. It involves complex logistical considerations, as well as profound challenges and anxieties relating to identity, social coherence and culture. In some cases, these have legal dimensions, relating to, for example, self-determination, citizenship and social and cultural rights.

\subsection{International institutions}

It was noted above that there is a greater need for whole-of-government approaches to

116 Jane McAdam, Interview with Anote Tong, President of Kiribati (Kiribati, 11 September 2013).

117 Nansen Initiative Pacific Report (n 2) 10-11, 17.

118 ibid 6.

119 See eg the International Law Association's Committee on International Law and Sea-Level Rise, which is currently examining these questions; McAdam, Climate Change, Forced Migration, and International Law (n 4) 119-60; Rosemary Rayfuse, 'International Law and Disappearing States: Maritime Zones and the Criteria for Statehood' (2011) 41 Enviro Policy \& L 281; Derek Wong, 'Sovereignty Sunk? The Position of “Sinking States” at International Law' (2013) 14 Melbourne J Intl L 346; Susin Park, 'Climate Change and the Risk of Statelessness: The Situation of Low-Lying Island States' (Legal and Protection Policy Research Series, UNHCR, May 2011) <http://www.unhcr.org/4df9cb0c9.html> accessed 4 June 2015.

120 Nansen Initiative Pacific Report (n 2) 21.

121 See further McAdam, 'Historical Cross-Border Relocations in the Pacific' (n 8). 
relocation at the national level. At the international level, too, there is also a need for a cross-pollination of ideas, action and responsibility. The specialist expertise of institutions across the areas of humanitarian assistance, human rights, development, disaster risk reduction, the environment and climate change is needed, but the end goal should be a holistic appraisal of the needs of particular communities, which necessarily requires information-sharing and coordination. Yet, there remains a problem of 'policy silos', reinforced by inconsistent budget/funding cycles, operational and mandate constraints, and the cumbersome UN bureaucracy which makes large-scale change slow to achieve. While there has been some useful and effective collaboration, such as the work of the Inter-Agency Standing Committee in the international climate change negotiations, which resulted in paragraph 14(f) of the Cancún Adaptation Framework, considerable disconnection between the various agencies remains. This risks the issues being dealt with in an ad hoc and fragmented manner. ${ }^{122}$

Difficulties already exist within some of the sectors mentioned above. The system of disaster management alone is 'highly fragmented, increasingly specialised, and marred by institutional rivalries. ${ }^{123}$ At times, agencies have resisted centralised control in the field, and there are vast differences in the nature and timeliness of their responses. This was apparent in the response to the 2004 Asian tsunami, where, notwithstanding significant resources,

the basic needs of displaced people were compromised by difficulties in coordinating the delivery of the US $\$ 6.8$ billion worth of assistance that was pledged, and the activities of the 16 UN agencies, 18 Red Cross response teams, 160 or more international NGOs, hundreds of private and civil-society groups, and 35 armed forces. ${ }^{124}$

The proliferation of many new actors in today's international humanitarian system means that good coordination is even more imperative.

Further, while the conversation has at least begun between the humanitarian and development communities, it is still largely disconnected from agencies like UNHabitat (now part of the Inter-Agency Standing Committee), which are working on climate change- and disaster-sensitive housing. Without a coordinated approach, there is a danger that communities may end up rebuilding in areas which lack sustainable livelihood opportunities and so on. These might not be issues to which an organisation like UN-Habitat would turn its attention.

The fact that planned relocation, like disaster response, is primarily the concern of individual governments may explain the absence of a concerted international

122 For detailed analysis of the relevant actors in this area, see McAdam, Climate Change, Forced Migration, and International Law (n 4) ch 8.

123 François Gemenne, 'Environmental Changes and Migration Flows: Normative Frameworks and Policy Responses' (PhD thesis, Institut d'Etudes Politiques de Paris and University of Liège 2009) 231.

124 Jon Barnett and Michael Webber, Accommodating Migration to Promote Adaptation to Climate Change (Commission on Climate Change and Development 2009) $34<\mathrm{http}: / / w w w . p r e v e n t i o n w e b . n e t / f i l e s / 11872$ AccommodatingMigration1.pdf> accessed 4 June 2015, referring to UNHCR, State of the World's Refugees: Human Displacement in the New Millennium (OUP 2006) ch 4. 
humanitarian effort on this front. However, there is clearly a need for the international community to support and monitor the need for and the execution of planned relocations, and to hold states accountable to their international human rights obligations in carrying out such actions.

Finally, if international institutional responses are not well coordinated, then ad hoc humanitarian assistance may become the default response of the international community. This is unlikely to be adequate in terms of its scale, timeliness, durability or comprehensiveness. It may also mean that the most vulnerable are not sufficiently protected.

\section{Conclusion}

Unpacking the term 'planned relocations' is a bit like unlocking Pandora's box: a host of complex issues emerge. In this article, we have suggested that the term 'relocation' refers to the process of physically moving communities, and this can be either voluntary or forced in nature, or somewhere in between. In contrast, the term 'resettlement', we suggest, is the process of re-establishing the community and living standards at least to the level which existed before the relocation. While relocation can occur without resettlement, resettlement cannot occur without relocation.

We have concentrated on relocations planned by state authorities, recognising that the degree to which particular governments can forward-plan, and actually implement such plans, varies enormously. We have noted some of the challenges of obtaining full and informed 'consent', arguing that community involvement in making decisions about relocation is essential-not only to distinguish between voluntary and forced movement, but also in its direct impact on the community's adjustment to life in the new location.

Overall, we have been struck by the lack of empirical evidence about the range of relocation efforts that has surely occurred in all regions. While there is a rich literature on relocations and resettlement in the context of development projects, the evidence base for communities relocated because of the effects of disasters or environmental conditions is more scattered. ${ }^{125}$ While a number of studies have been carried out on Pacific Island countries, and indeed reference has been made to them in this article, it is difficult to know if the experiences of Pacific Islanders can be applied to other regions. A few academic researchers have examined specific cases of disaster-induced relocations, and the World Bank has collected cases in which communities have been relocated as a preventative measure. ${ }^{126}$ But the number of cases of planned relocation is certainly far larger and warrants further attention. For example, the Chinese government is reported

125 For a review of the literature, see Daniel Petz, Planned Relocations in the Context of Natural Disasters and Climate Change: A Review of the Literature (Brookings Institution 2015) and other background materials prepared for the May 2015 Bellagio Consultation (n 6); case studies in various articles contained in (2015) 49 Forced Migration Rev.

126 Correa (n 65). 
to have relocated millions of people for 'environmental reasons', but these cases are not widely known outside that country. African governments have relocated populations from flood plains, at least a few US towns and cities have moved in response to environmental factors, and Asian governments have been involved in relocating populations. Not only is further academic work needed on these specific cases, but efforts should also be made to compile existing research to serve as a resource for those working on planned relocations in the context of climate change. Indeed, McAdam argues that contemporary relocation should be understood within a much longer, global history of movement. She prompts us to consider eighteenth- and nineteenth-century settler colonialism and twentiethcentury population transfers as exercises in planned relocation, noting that, for the first half of the twentieth century, the international community was preoccupied with elaborate resettlement plans as a means of redistributing global population to alleviate overcrowding and resource scarcity (and thereby, it was assumed, the risk of conflict). ${ }^{127}$

There are other conceptual issues that have not been addressed in this article which need further exploration. For example, to what extent does terminology shape understandings of the processes underway, and in turn affect policy development? For example, some Alaskan and Pacific communities that have relocated, or wish to relocate, view themselves as pioneers or settlers, which conveys a very different meaning compared to when people consider themselves to be displaced or forcibly relocated. The issue of planned relocation also emphasises the importance of governmental intentions in relocating communities, particularly when it means appropriating property or imposing restrictions on freedom of movement.

Moreover, most of the existing research on relocation focuses on its impact on those who move, rather than on the receiving or host communities, or on those who remain behind. These communities are also necessarily affected by relocations.

In the context of climate change, planned relocation highlights the thorny intersection between science and policy. How can the impact of climate change on habitability of land be assessed, particularly when it almost always interacts with human action? To what extent should scientists be involved in determining when an area becomes uninhabitable? And should decision-makers wait until the evidence is clear that people can no longer survive where they live, or do they have a responsibility to move people before the situation reaches that point?

Finally, planned relocation is an issue of justice. Those who are able to migrate will likely do so before the situation becomes desperate, while those without the necessary financial or social means will be dependent on governmental assistance to support their relocation. If that is not forthcoming, then they will be stuck.

127 Jane McAdam, 'Relocation and Resettlement from Colonisation to Climate Change: The Perennial Solution to "Danger Zones"” (2015) 3 London Rev of Intl Law 93. 